\title{
ESTUdO RETROSPECTIVO DE RESSONÂNCIA MAGNÉTICA EM PACIENTES COM MIELOPATIAS (SUB) AGUDAS
}

\author{
Paulo A. Y. Okuda*, Vanessa M. Brito, Fabiano Reis.
}

\section{Resumo}

Mielite transversa longitudinal extensa é uma lesão que afeta segmentos medulares, que, em geral, associa-se a déficits motores graves, sendo fundamental o rápido diagnóstico etiológico. Apresenta múltiplos diagnósticos diferenciais, sendo assim, o objetivo desse trabalho foi verificar o papel da ressonância magnética na determinação desses diagnósticos e definir quais foram os padrões de imagem observados em cada um deles

\section{Palavras-chave:}

Mielite transversa longitudinal extensa, ressonância magnética, diagnóstico diferencial

\section{Introdução}

Mielite transversa longitudinal extensa (MTLE) é uma lesão hiperintensa em ressonância magnética (RM) ponderada em T2 que afeta, longitudinalmente 3 ou mais segmentos medulares, e transversalmente mais do que dois terços da medula, que, em geral se associa a déficits motores importantes, sendo fundamental o estabelecimento do diagnóstico etiológico para orientar o tratamento. Apresenta consequências clínicas graves, de modo que, uma avaliação sistemática para o reconhecimento de sua etiologia e um tratamento precoce e eficaz é de suma importância, não só para um prognóstico funcional a curto e longo prazo, mas também para se prevenir danos futuros à medula espinhal e/ou ao sistema nervoso central (SNC), quando sua etiologia estiver associada a causas infecciosas, metabólicas ou desmielinizantes inflamatórias.

Os sintomas mais comuns encontrados em pacientes acometidos pela MTLE são: disfunção urinária e intestinal, paraplegia, tetraplegia, perda da acuidade visual, déficit sensorial e, em casos graves, colapso da função respiratória.

Existem múltiplos diagnósticos diferenciais para a MTLE: Neuromielite Óptica (NMO), esclerose múltipla (EM), encefalomielite disseminada aguda, doenças autoimunes sistêmicas (sarcoidose), infecciosas (viral, micótica, bacteriana e parasitária), paraneoplásicas, metabólicas (carência de vitamina B12), entre outras.

Para diagnosticar as doenças do espectro da $\mathrm{NMO}$, existem os biomarcadores NMO-IgG e anti-MOG. No entanto, seu diagnóstico definitivo ainda requer análise de imagens de RM. Para o diagnóstico de EM e encefalomielite disseminada aguda, é necessária a análise de RM do cérebro e da medula espinhal do paciente, do líquido cefalorraquidiano (LCR), bem como do seu histórico médico. No caso da sarcoidose, o diagnóstico pode ser feito através de exame histológico, indicando a presença de granulomas, excluindo-se outras causas de doenças granulomatosas. Além disso, na sarcoidose, o estudo de imagem do tórax pode ser útil, pois a presença de padrões sugestivos da doença, como linfonodomegalias hílares e nódulos perilinfáticos, pode permitir a definição etiológica a partir de biópsia de tórax, que é menos invasiva, e tem menos repercussões que a biópsia de medula. O diagnóstico de síndromes paraneoplásicas é feito por meio de biomarcadores, como o CRMP-5-IgG e a anfifisina-lgG. No caso da MTLE de etiologia infecciosa, punção lombar e testes sanguíneos são importantes para o diagnóstico.
Em muitos quadros clínicos da MTLE, não existem testes/exames específicos que permitam fazer o diagnóstico definitivo dessa doença. Dessa forma, a RM torna-se uma ferramenta paraclínica fundamental para o estudo de pacientes com quadros clínicos de lesões medulares.

\section{Resultados e Discussão}

Alguns padrões de imagem permitiram diagnósticos bastante precisos, destacando-se:

Presença de lesões nodulares, com periferia hipointensa, captante de contraste, sugere etiologia granulomatosa;

Lesões com restrição à difusão, em cornos anteriores, com padrão de "olho de coruja" são encontradas em isquemias medulares agudas;

Lesões sólido-císticas, eventualmente com hemorragia associada, e com realce na porção sólida podem sugerir tumor;

Lesões em segmentos mais curtos, com realce homogêneo pelo meio de contraste, podem favorecer desmielinização focal, como EM (a RM de encéfalo nestes casos auxilia para o diagnóstico correto);

Lesões medulares mais extensas, com realce pelo meio de contraste, em pacientes com antecedente de neurite óptica, apontam para doenças do espectro da neuromielite óptica;

Lesões no funículo posterior, contínuas, podem ser observadas em algumas situações, como carência de B12 (mais frequente), neurossífilis ("tabes dorsalis"), deficiência de cobre e sarcoidose.

\section{Conclusões}

Pacientes com mielopatia aguda ou subaguda podem apresentar sintomatologias diversas, dependendo da etiologia e da localização dos achados neurológicos. Portanto, a RM tem um papel fundamental no auxílio à orientação de um diagnóstico correto, permitindo que seja feito um tratamento clínico adequado.

\section{Agradecimentos}

Agradeço ao PIBIC/CNPq pelo apoio financeiro dado ao projeto, ao meu orientador Professor Doutor Fabiano Reis pela confiança e ensinamentos e à residente Vanessa Mizubuti Brito pelo auxílio durante todo este trabalho.

Grayev, A. M., Kissane, J., \& Kanekar, S. (2014). Imaging Approach to the Cord T2 Hyperintensity (Myelopathy). Radiologic Clinics of North America, 52(2), 427-446.doi:10.1016/j.rcl.2013.11.002

Kranz, P. G., \& Amrhein, T. J. (2018). Imaging Approach to Myelopathy.

Radiologic Clinics of North America.doi:10.1016/j.rc1.2018.09.006 